\title{
Analysis of adherence to HIV-positive quality of care indicators and their impact on service quality perceptions in patients: a Spanish cross-sectional study
}

\author{
A. Gimeno-García ${ }^{1,2^{*}}$ D, A. Franco-Moreno ${ }^{1}$, C. Montero-Hernández,2, S. Arponen', E. García-Carrasco ${ }^{3}$, B. Alejos ${ }^{4}$, \\ D. Corps-Fernández ${ }^{1,2}$, E. Gaspar-García ${ }^{5}$, P. Galindo-Jara ${ }^{2,6}$, M. García-Navarro ${ }^{1}$ and D. Varillas-Delgado
}

\begin{abstract}
Background: Since the identification of human immunodeficiency virus (HIV) infection, there have been significant advances in its diagnosis and treatment, but there have been few contributions to the area of care quality. In 2010, the Spanish AIDS Study Group (GeSIDA) published the document "Health quality indicators of GeSIDA for the care of people infected with HIV/AIDS" in which standards are proposed for the purpose of improving and standardizing the assistance provided to people infected with HIV. The purpose of this study was to evaluate the degree of compliance with these indicators and to analyse whether adherence to the standards improves patient perception of care quality in terms of their satisfaction with the health care they have received.
\end{abstract}

Methods: Compliance with GeSIDA indicators was analysed within a cohort of people living with HIV (PLHIV) in a hospital in the Madrid region. To evaluate patient perception, the External Consultation User Satisfaction Questionnaire (SUCE) was used, which is a tool that was previously validated in the Spanish population.

Results: A total of 334 patients were included. The level of adherence to the indicators was $74.46 \%$. The score on the SUCE questionnaire was 9.04 out of 10 (CI 95\%: 8.90-9.19). Of the 47 indicators assessed, only 4 were related to satisfaction with health care.

Conclusions: The levels of compliance with the indicators and patient satisfaction with health care were high. Adherence to quality indicators showed little relation to patient-reported satisfaction.

Keywords: HIV, Acquired immunodeficiency syndrome, Quality indicators, Health care: patient satisfaction

\section{Background}

The desire to improve the quality of health care has led to the development of assessment tools [1]. Donabedian's study [2] established the basis of the quality systems applied to health care and defined quality as " $a n$

\footnotetext{
* Correspondence: agimeno@torrejonsalud.com

'Servicio de Medicina Interna, Hospital Universitario de Torrejón. Calle Mateo Inurria S/N. 28850, Torrejón de Ardoz, Madrid, Spain

2Universidad Francisco de Vitoria, Carretera Pozuelo-Majadahonda km 1.800, 28223 Pozuelo de Alarcón, Madrid, Spain

Full list of author information is available at the end of the article
}

adaptation of the attention to the particular needs of each case", highlighting that the majority of health care evaluations are limited to a recounting of the actions undertaken, without taking into consideration their effects on health or the extent to which they meet the needs of patients. In recent years, demand has grown for health care that, in addition to being effective and evidence-based, is perceived as satisfactory and beneficial by the patient [3]. This perspective is especially important in patients with chronic diseases, such as infection

(c) The Author(s). 2020 Open Access This article is licensed under a Creative Commons Attribution 4.0 International License, which permits use, sharing, adaptation, distribution and reproduction in any medium or format, as long as you give appropriate credit to the original author(s) and the source, provide a link to the Creative Commons licence, and indicate if changes were made. The images or other third party material in this article are included in the article's Creative Commons licence, unless indicated otherwise in a credit line to the material. If material is not included in the article's Creative Commons licence and your intended use is not permitted by statutory regulation or exceeds the permitted use, you will need to obtain permission directly from the copyright holder. To view a copy of this licence, visit http://creativecommons.org/licenses/by/4.0/ The Creative Commons Public Domain Dedication waiver (http://creativecommons.org/publicdomain/zero/1.0/) applies to the data made available in this article, unless otherwise stated in a credit line to the data. 
with the human immunodeficiency virus (HIV), since clinical and physiological measurements provide valuable information for the physician but are often poorly correlated with functional capacity and patient welfare [4]. In the case of patients with HIV infection, the Spanish AIDS Study Group (GeSIDA) published a document in 2010 that includes 66 indicators of care quality. Currently, patients with HIV infection have a longer life expectancy than they did historically and accumulate more comorbidities, which means that health professionals need to address issues beyond virological suppression [5]. User satisfaction is one of the most relevant characteristics that can be used to measure the quality of a service and serves as the basis for the formulation of appropriate health policies [6, 7].

Information reported by patients allows the implementation of actions to improve health care [8]. Some very important elements of health care, such as the perception of the results from the patient's perspective, are poorly represented in the current health care indicators [9]. In this context, it seems especially relevant to monitor whether there is a relationship between the quality of care achieved through compliance with the established quality standards and the quality of care as perceived by the patient.

The aim of this study was to evaluate the compliance with the quality indicators established by the GeSIDA in a cohort of people living with HIV (PLHIV) and to analyse the influence of those indicators on patient satisfaction. Although some articles have been published on the indicators of the quality of care in the HIV-positive population in different contexts and their relationships with different factors $[10,11]$, the impact of those indicators on patient satisfaction has not been analysed.

\section{Methods}

\section{Study design}

This was a cross-sectional observational study of an HIV-positive Spanish population.

\section{Patients}

In the analysis of compliance with the quality indicators, all PLHIV over 18 years of age who started or continued follow-up during the study period between September 2011 and November 2017 were included.

For the analysis of patient-reported satisfaction, patients who were not participating in active follow-up at the time of the survey (due to death, transfer to another centre or loss to follow-up), those who were not able to respond (due to illiteracy, language barriers or poor baseline situation), and those who declined to participate were excluded.

The work was carried out in accordance with the Helsinki declaration of 1974 (updated in 2000) and current personal data protection regulations. It was approved by the Research Commission of the study centre and by the Ethics Committee of the hospital. All patients included in the satisfaction analysis signed the patient information sheet and provided informed consent.

\section{Quality indicators}

The indicators of the quality of care for HIV-positive patients proposed by GeSIDA were used. There were 66 indicators published in 2010 [12], which were subsequently validated, demonstrating their reproducibility and feasibility [13]. The indicators that all HIV units should monitor to determine their status and identify necessary improvement measures are considered relevant. The indicators that must meet the established standard so that the unit can be accredited are called basic [12]. All the basic and relevant indicators were analysed except for three: indicators 9-Relevant contents of the initial assessment and 33-Periodic consultation report could not be evaluated because the necessary data were not available; neither indicator is considered relevant. Indicator 52-Specific treatment of chronic hepatitis $C$ virus $(\mathrm{HCV})$ was not analysed because during the study period, the treatment of chronic hepatitis $C$ was based on direct-acting antiviral drugs and not on interferon and ribavirin, as stated in the definition of the indicator.

The analysis of compliance with the indicators was carried out by the research team following the definitions established by the GeSIDA experts. The information necessary for the evaluation was obtained from the electronic medical records and was collected in a specifically designed database.

\section{Study variables}

To achieve the main goal of the study, patient satisfaction was analysed by means of the survey "External Consultation User Satisfaction Questionnaire" (SUCE), a self-reported previously validated in the Spanish population [14]. It consists of 12 items with a response scale from 1 , the worst rating, to 10 , the best rating. It allows the independent evaluation of the clinical quality by analysing aspects related to care by health personnel and the administrative quality by analysing organizational and structural aspects. By means of ROC curves, 6.3 was established as a cut-off point to discriminate between satisfied and unsatisfied patients [15].

The questionnaires were offered in English and Spanish at the end of the consultation, and the patients answered them in a separate space, depositing them at the end in an container located in the administrative area of the centre.

Other relevant variables, such as age, sex, educational level, country of origin, date of diagnosis of HIV 
infection, transmission mechanism, CD4+ cell count and HIV viral load (VL), were analysed.

\section{Statistical analysis}

All analyses were performed with the statistical program STATA 14 College Station, TX.

A descriptive analysis of the basic characteristics of all the patients was performed; frequency distributions were used for categorical variables, and means (standard deviations) or medians (interquartile ranges) were used for continuous variables, based on the normality of their distributions. These characteristics were compared between all patients and those participating in the survey with the chi-square test and Student's t-test to assess the representativeness of the sample.

Forty-seven indicators of the quality of care were evaluated with their 95\% parametric confidence intervals (CIs). An indicator was met when the $95 \% \mathrm{CI}$ of the compliance percentage contained the value defined as the standard.

Linear regression models were used to estimate the differences in means and 95\% CIs with regard to the effect of compliance with the indicators on patient satisfaction. For the regression analyses, the indicators calculated at the individual level were included for the patients who participated in the interviews.

To study which quality indicators were independently associated with satisfaction, multivariable regression models were constructed, in which independent variables were included in addition to the indicators age, sex, transmission mechanism, country of origin, CD4+ cell count and VL at the time the questionnaire was completed. Those variables with $p<0.05$ were retained in the model.

\section{Results}

A total of 334 patients with HIV infection were treated in the outpatient clinic between September 2011 and November 2017. Table 1 shows the descriptive analysis of the patients. A total of $64.1 \%$ of the patients were men. Forty-four were foreigners, and sub-Saharan Africa was the most frequent place of origin (24.4\%). Fifty percent of the patients had been diagnosed before 2007 (IQR; 1996; 2013), and the most frequent infection risk category was heterosexual (43.2\%), followed by parenteral drug addict (PDA) (28.4\%) and men who have sex with men (MSM) (25.4\%). On the first visit to the centre, the median age was 42 years (IQR: $35 ; 49$ ), the median CD4+ lymphocyte count was 457 cells $/ \mathrm{mm}^{3}$ (CI: 219 ;

Table 1 Characteristics of patients treated in the HIV program stratified by survey participation

\begin{tabular}{|c|c|c|c|c|c|}
\hline & $\begin{array}{l}\text { Lost to follow-up, transferred, } \\
\text { dead }\end{array}$ & $\begin{array}{l}\text { Did not respond to } \\
\text { survey }\end{array}$ & $\begin{array}{l}\text { Responded to } \\
\text { survey }\end{array}$ & Total & $P$ value \\
\hline Number & 93 & 77 & 164 & 334 & \\
\hline Sex & & & & & 0.664 \\
\hline Male & $61(65.6 \%)$ & 46 (59.7\%) & $107(65.2 \%)$ & $214(64.1 \%)$ & \\
\hline Female & 32 (34.4\%) & 31 (40.3\%) & $57(34.8 \%)$ & $120(35.9 \%)$ & \\
\hline Transmission & & & & & 0.005 \\
\hline PDA & 35 (37.6\%) & $18(23.4 \%)$ & $42(25 . t 6 \%)$ & 95 (28.4\%) & \\
\hline Unknown & $1(1.1 \%)$ & $5(6.5 \%)$ & $2(1.2 \%)$ & $8(2.4 \%)$ & \\
\hline MSM & 15 (16.1\%) & $14(18.2 \%)$ & $56(34.1 \%)$ & 85 (25.4\%) & \\
\hline Heterosexual & 42 (45.2\%) & 40 (51.9\%) & $62(37.8 \%)$ & $144(43.2 \%)$ & \\
\hline Blood transfusion & $0(0.0 \%)$ & $0(0.0 \%)$ & $1(0.6 \%)$ & $1(0.3 \%)$ & \\
\hline Vertical & $0(0.0 \%)$ & $0(0.0 \%)$ & $1(0.6 \%)$ & $1(0.3 \%)$ & \\
\hline Country of origin & & & & & 0.024 \\
\hline Spain & $56(60.2 \%)$ & $36(46.8 \%)$ & $107(65.2 \%)$ & 199 (59.6\%) & \\
\hline Other & 37 (39.8\%) & 41 (53.2\%) & 57 (34.8\%) & $135(40.4 \%)$ & \\
\hline Age at first visit, years & $44.2(37.2 ; 49.3)$ & $41.6(31.9 ; 48.8)$ & $42.1(34.1 ; 47.4)$ & $42.3(34.6 ; 48.5)$ & 0.645 \\
\hline \multicolumn{6}{|l|}{ Viral load at first visit } \\
\hline Undetectable $(<50$ copies/ml) & $34(36.6 \%)$ & 39 (50.6\%) & $62(37.8 \%)$ & $135(40.4 \%)$ & 0.143 \\
\hline $\begin{array}{l}\text { CD4+ cell count at first visit (cells/ } \\
\mathrm{mm}^{3} \text { ) }\end{array}$ & $413.0(179.0 ; 639.0)$ & $491.0(237.0 ; 747.0)$ & $474.0(215.5 ; 698.0)$ & $\begin{array}{l}457.0(219.0 ; \\
685.0)\end{array}$ & 0.227 \\
\hline Years of follow-up & $1.0(0.2 ; 1.8)$ & $4.3(2.9 ; 5.1)$ & $3.6(2.0 ; 4.8)$ & $2.9(1.0 ; 4.6)$ & $<0.001$ \\
\hline
\end{tabular}


$685)$, and $40.4 \%$ had undetectable plasma VLs. The median follow-up time in the centre was 3 years (IQR: $1 ; 5$ ).

To calculate the quality indicators, 334 PLHIV treated in the outpatient clinic during the study period were included. At the time of the survey, 93 patients were not being followed up (lost to follow-up, transferred or died), and 43 patients were excluded due to illiteracy, language barriers, organic or psychiatric pathology that made it impossible for them to complete the questionnaire or refusal to participate. Of the 198 surveys administered, 172 were collected ( $87 \%$ response rate). In the satisfaction analysis, 164 patients were included because 8 surveys were not valid (Fig. 1).

There were differences between patients included and excluded in the survey analysis. The percentage of participation in the surveys was higher in patients with longer follow-up times $(p<0.001), \operatorname{MSM}(p=$
$0.005)$ and patients of Spanish nationality $(p=0.038)$ (Table 1).

\section{Quality indicators and user satisfaction}

Compliance with the quality indicators was high: of the 47 indicators evaluated, 35 met the established standard (74.46\%). Table 2 shows the results of compliance with each of the indicators. The SUCE scale score was 9.04 (95\% CI: 8.90; 9.19) (Fig. 2). Based on the proposed cutoff value of 6.3 [15], 98.16\% of the patients were satisfied. The Clinical Quality Factor Score (9.48, 95\% CI: 9.37;9 .60) was higher than the Administrative Quality Score $(8.56$, 95\% CI: 8.35; 8.76). Table 3 shows the univariate analysis of quality indicators related to satisfaction (SUCE). Those related to greater satisfaction were 16-Periodicity of visits [difference in means 95\% CI: 0.62 $(0.13 ; 1.11)], 21$-Vaccination against hepatitis $A$ [difference in means 95\% CI: $1.14(0.16 ; 2.12)]$ and 23-

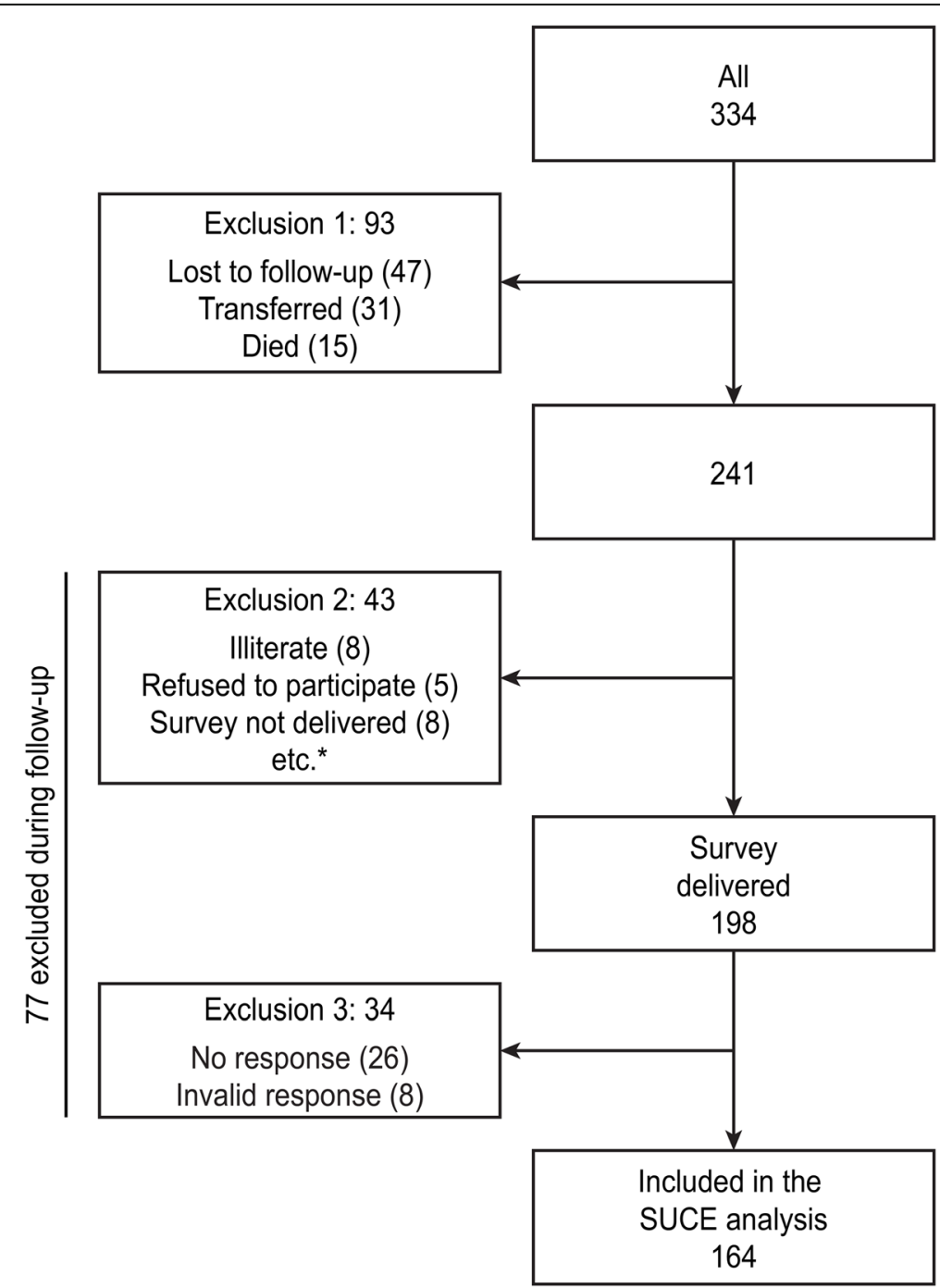

Fig. 1 General outline of the study: patients included between 2011 and 2017 
Table 2 Quality indicators for all patients evaluated

\begin{tabular}{|c|c|c|c|c|c|c|c|c|}
\hline \multirow[t]{2}{*}{ N } & \multirow[t]{2}{*}{ Indicator } & \multirow{2}{*}{$\begin{array}{l}\text { Patients evaluated by the } \\
\text { indicator } \\
\text { (N) }\end{array}$} & \multicolumn{4}{|c|}{$\begin{array}{l}\text { Patients who met the } \\
\text { indicator }\end{array}$} & \multirow{2}{*}{$\begin{array}{l}\text { Standard set by } \\
\text { GeSIDA } \\
(\%)\end{array}$} & \multirow{2}{*}{$\begin{array}{l}\text { Compliance } \\
\text { with the } \\
\text { indicator in } \\
\text { the study }\end{array}$} \\
\hline & & & $(N)$ & (\%) & (Cl 95 & 5\%) & & \\
\hline 1 & Specialized doctor care & & & 100 & & & $100 \%$ & Yes \\
\hline 2 & Availability of diagnostic resources & & & 100 & & & Yes (all) & Yes \\
\hline 3 & External pharmacy for dispensing drugs & & & No & & & Yes & No \\
\hline 4 & Conditions of privacy and structural confidentiality & & & 100 & & & $100 \%$ & Yes \\
\hline 6 & Delay in referral to specialized care & 47 & 42 & 89.4 & 76.9 & 96.5 & $100 \%$ & No \\
\hline 7 & Late diagnosis of HIV in specialized care & 106 & 28 & 26.4 & 18.3 & 35.9 & $<25 \%$ & Yes \\
\hline 8 & HIV diagnosis with previous negative serology & 106 & 64 & 60.4 & 50.4 & 69.7 & $80 \%$ & No \\
\hline 10 & Complementary tests in the initial assessment & 334 & 322 & 96.4 & 93.8 & 98.1 & $95 \%$ & Yes \\
\hline 11 & HIV plasma viral load & 334 & 334 & 100 & 98.9 & 100 & $100 \%$ & Yes \\
\hline 12 & Determination of lymphocyte subpopulations (CD4) & 334 & 334 & 100 & 98.9 & 100 & $100 \%$ & Yes \\
\hline 13 & Health education at initial assessment & 332 & 187 & 56.3 & 50.8 & 61.7 & $95 \%$ & No \\
\hline 15 & $\begin{array}{l}\text { Indication of treatment with }<350 \text { CD4 and } \\
\text { without prior ART }\end{array}$ & 117 & 3 & 2.6 & 0.5 & 7.3 & $<10 \%$ & Yes \\
\hline 16 & Periodicity of visits (regular follow-up) & 218 & 193 & 88.5 & 83.5 & 92.4 & $85 \%$ & Yes \\
\hline 17 & Basic renal study in HIV+ patients & 212 & 209 & 98.6 & 95.9 & 99.7 & $100 \%$ & Yes \\
\hline 20 & LTI detection & 189 & 110 & 58.2 & 50.8 & 65.3 & $90 \%$ & No \\
\hline 21 & Vaccination against hepatitis $A$ & 58 & 54 & 93.1 & 83.3 & 98.1 & $85 \%$ & Yes \\
\hline 22 & Vaccination against hepatitis $B$ & 88 & 81 & 92.0 & 84.3 & 96.7 & $85 \%$ & Yes \\
\hline 23 & Vaccination against pneumococcal infection & 213 & 193 & 90.6 & 85.9 & 94.2 & $85 \%$ & Yes \\
\hline 24 & $\begin{array}{l}\text { Prophylaxis against Pneumocystis jirovecii and } \\
\text { Toxoplasma }\end{array}$ & 42 & 41 & 97.6 & 87.4 & 99.9 & $100 \%$ & Yes \\
\hline 25 & Treatment and prevention of smoking & 93 & 67 & 72.0 & 61.8 & 80.9 & $95 \%$ & No \\
\hline 26 & Alcohol intake assessment & 218 & 8 & 3.7 & 1.6 & 7.1 & $95 \%$ & No \\
\hline 29 & Syphilis screening & 149 & 68 & 45.6 & 37.5 & 54.0 & $70 \%$ & No \\
\hline 30 & LTI treatment & 25 & 23 & 92.0 & 74.0 & 99.0 & $95 \%$ & Yes \\
\hline 31 & Loss to follow-up & 255 & 14 & 5.5 & 3.0 & 9.0 & $\leq 5 \%$ & Yes \\
\hline 32 & Recovery of failed appointments & & & 84.9 & & & $85 \%$ & Yes \\
\hline 35 & Adaptation of initial ART to the guidelines & 119 & 119 & 100 & 96.9 & 100 & $95 \%$ & Yes \\
\hline 36 & $\begin{array}{l}\text { Initiation of ART in patients with symptomatic B/C } \\
\text { events }\end{array}$ & 33 & 32 & 97.0 & 84.2 & 99.9 & $90 \%$ & Yes \\
\hline 37 & First visit after the establishment of ART & 117 & 108 & 92.3 & 85.9 & 96.4 & $90 \%$ & Yes \\
\hline 38 & Undetectable viral load $(<50$ copies $/ \mathrm{ml})$ at week 48 & 106 & 102 & 96.2 & 90.6 & 99.0 & $80 \%$ & Yes \\
\hline 39 & $\begin{array}{l}\text { Treatment with Abacavir (ABC) without previous } \\
\text { HLA-B } 5701\end{array}$ & 77 & 0 & 0 & 0 & 4.7 & $0 \%$ & Yes \\
\hline 40 & Treatment changes during the first year & 98 & 20 & 20.4 & 12.9 & 29.7 & $<30 \%$ & Yes \\
\hline 41 & Record of adherence to treatment & 312 & 266 & 85.3 & 80.8 & 89.0 & $95 \%$ & No \\
\hline 42 & Study of resistance in case of virologic failure & 45 & 41 & 91.1 & 78.8 & 97.5 & $90 \%$ & Yes \\
\hline 44 & Average expenditure per patient in first treatment & 13 & & $8710.8^{*}$ & & & ** & Yes \\
\hline 45 & ART in pregnant women with HIV & 17 & 17 & 100 & 80.5 & 100 & $100 \%$ & Yes \\
\hline 47 & Vertical transmission incidence & 17 & 0 & 0 & 0 & 19.5 & $<1 \%$ & Yes \\
\hline 49 & $\begin{array}{l}\text { Evaluation by CHILD or MELD for chronic liver } \\
\text { disease }\end{array}$ & 12 & 6 & 50.0 & 21.1 & 78.9 & $100 \%$ & No \\
\hline 50 & Evaluation of hepatitis $C$ virus coinfection & 7 & 7 & 100 & 59.0 & 100 & $90 \%$ & Yes \\
\hline 54 & HBsAg patients receiving effective treatment & 12 & 12 & 100 & 73.5 & 100 & $90 \%$ & Yes \\
\hline
\end{tabular}


Table 2 Quality indicators for all patients evaluated (Continued)

\begin{tabular}{|c|c|c|c|c|c|c|c|c|}
\hline \multirow[t]{2}{*}{ N } & \multirow[t]{2}{*}{ Indicator } & \multirow{2}{*}{$\begin{array}{l}\text { Patients evaluated by the } \\
\text { indicator } \\
(N)\end{array}$} & \multicolumn{4}{|c|}{$\begin{array}{l}\text { Patients who met the } \\
\text { indicator }\end{array}$} & \multirow{2}{*}{$\begin{array}{l}\text { Standard set by } \\
\text { GeSIDA } \\
(\%)\end{array}$} & \multirow{2}{*}{$\begin{array}{l}\text { Compliance } \\
\text { with the } \\
\text { indicator in } \\
\text { the study }\end{array}$} \\
\hline & & & $(N)$ & (\%) & (Cl 95 & & & \\
\hline 55 & Ultrasound control in cirrhotic patients & 8 & 4 & 50.0 & 15.7 & 84.3 & $90 \%$ & No \\
\hline 56 & Cardiovascular risk assessment & 212 & 120 & 56.6 & 49.6 & 63.4 & $90 \%$ & No \\
\hline 58 & Patients with discharge report after hospitalization & 80 & 80 & 100 & 95.5 & 100 & $100 \%$ & Yes \\
\hline 59 & $\begin{array}{l}\text { Reports of discharge of deceased patients in the } \\
\text { hospital }\end{array}$ & 12 & 12 & 100 & 73.5 & 100 & $100 \%$ & Yes \\
\hline 60 & $\begin{array}{l}\text { Follow-up in outpatient clinic after hospital } \\
\text { discharge }\end{array}$ & 74 & 74 & 100 & 95.1 & 100 & $100 \%$ & Yes \\
\hline 62 & Overall mortality rate in patients in follow-up & 334 & 15 & 11.7 & 8.7 & 24.9 & $\leq 25^{* * *}$ & Yes \\
\hline 63 & Mortality rate due to AIDS-related causes & 334 & 3 & 3.2 & 1.0 & 9.8 & Not established & \\
\hline 64 & Continuing education & & & 100 & & & $75 \%$ & Yes \\
\hline
\end{tabular}

* Cost in euros of initiating treatment in this population

** Median rates published in the corresponding year by GeSIDA (7506.5 (6556-9072)) [16]

*** Death rate per 1000 people/year

Vaccination against pneumococcal infection [mean difference 95\% CI: 0.74 (0.10;1.38).

In contrast, those who met the 26-Evaluation of alcohol intake had a lower level of satisfaction [95\% difference in means 95\% CI: $-1.20(-1.97 ;-0.44)]$. Foreign patients reported greater satisfaction than Spaniards [95\% CI difference: $0.42 \quad(0.12 ; 0.71)]$ (Table 4).

Table 5 shows the multivariable analysis of satisfaction-related factors (SUCE). The final satisfaction model included the indicator 16-Periodicity of visits (regular follow-up) and country of origin.

\section{Discussion}

The baseline characteristics of the 334 patients treated at the centre were significantly different from those of other Spanish cohorts $[17,18]$, with a higher percentage of foreigners (40.42\%), mainly from sub-Saharan Africa. This may account for the fact that the most common risk category was HTSX and not MSM, as in other published series. Although the male sex predominated, there were more women (36\%) than usual in this type of study [18].

Of the 198 surveys administered, 172 were collected, with a response rate of $87 \%$, which is much higher than

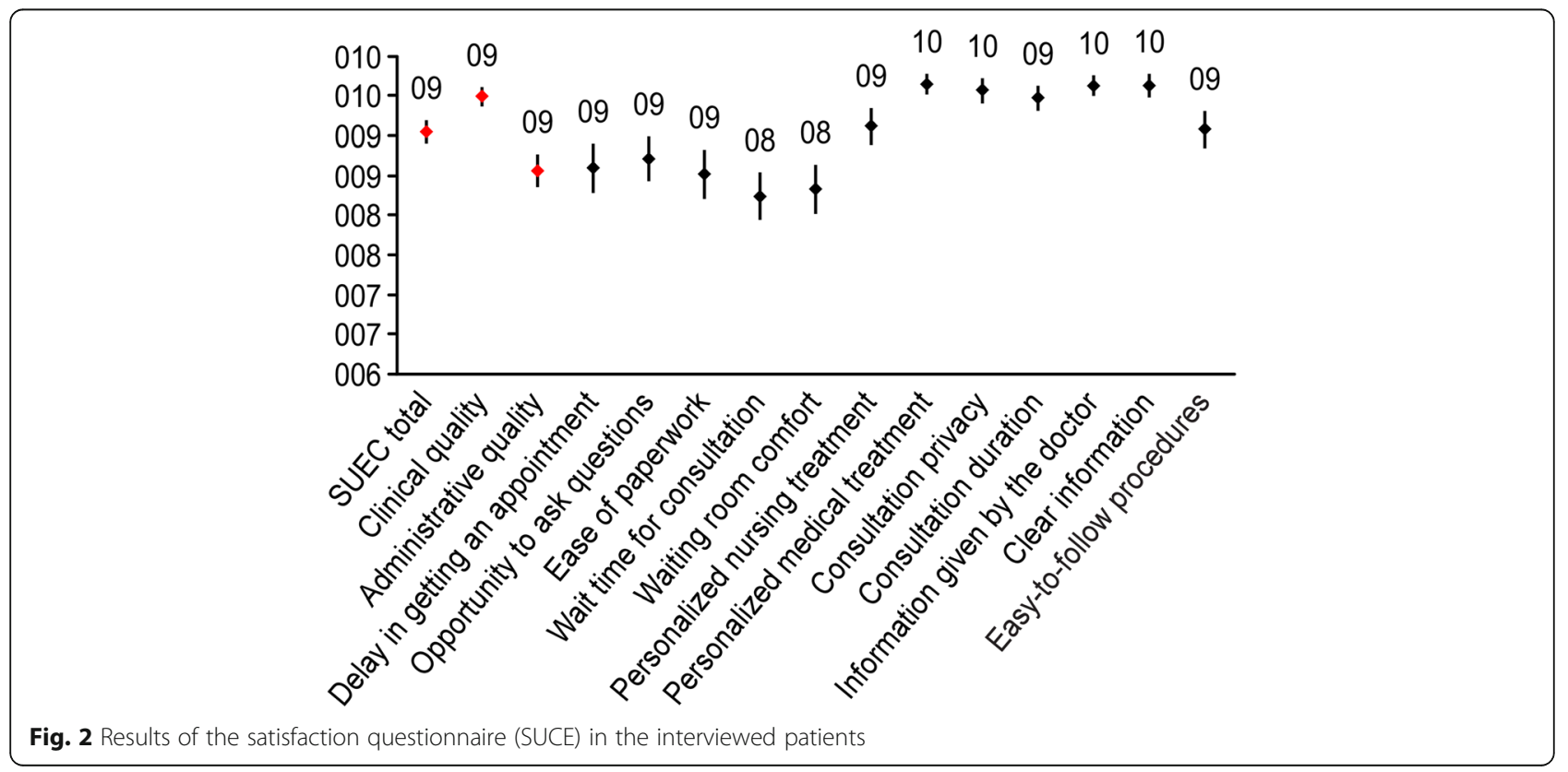


Table 3 Univariate analysis of quality indicators related to satisfaction (SUCE)

\begin{tabular}{|c|c|c|}
\hline \multirow[t]{2}{*}{ N } & \multirow[t]{2}{*}{ Healthcare quality indicator } & \multirow{2}{*}{$\begin{array}{l}\text { SUCE } \\
\text { Mean difference (CI 95\% }\end{array}$} \\
\hline & & \\
\hline 6 & Delay in referral to specialized care & $-0.26(-1.33 ; 0.81)$ \\
\hline 7 & Late diagnosis of HIV in specialized care & $-0.23(-0.81 ; 0.35)$ \\
\hline 8 & HIV diagnosis with previous negative serology & $-0.10(-0.65 ; 0.44)$ \\
\hline 10 & Complementary tests in the initial assessment & $0.01(-1.07 ; 1.10)$ \\
\hline 11 & HIV plasma viral load & - \\
\hline 12 & Determination of lymphocyte subpopulations (CD4) & - \\
\hline 13 & Health education at initial assessment & $0.24(-0.06 ; 0.54)$ \\
\hline 15 & Indication of treatment with $<350$ CD4 and without prior ART & - \\
\hline 16 & Periodicity of visits (regular follow-up) & $0.62(0.13 ; 1.11)^{*}$ \\
\hline 17 & Basic renal study in HIV+ patients & $-0.57(-2.49 ; 1.35)$ \\
\hline 20 & LTI detection & $0.09(-0.27 ; 0.44)$ \\
\hline 21 & Vaccination against hepatitis $\mathrm{A}$ & $1.14(0.16 ; 2.12)^{*}$ \\
\hline 22 & Vaccination against hepatitis B & $0.49(-0.41 ; 1.40)$ \\
\hline 23 & Vaccination against pneumococcal infection & $0.74(0.10 ; 1.38)^{*}$ \\
\hline 24 & Prophylaxis against Pneumocystis jirovecii and Toxoplasma & $-0.14(-3.03 ; 2.76)$ \\
\hline 25 & Treatment and prevention of smoking & $0.11(-0.52 ; 0.75)$ \\
\hline 26 & Alcohol intake assessment & $-1.20(-1.97 ;-0.44)^{*}$ \\
\hline 29 & Syphilis screening & $0.03(-0.35 ; 0.41)$ \\
\hline 30 & LTI treatment & $-0.60(-2.18 ; 0.98)$ \\
\hline 35 & Adaptation of initial ART guidelines to the guidelines & - \\
\hline 36 & Initiation of ART in patients with symptomatic $B / C$ events & - \\
\hline 37 & First visit after the establishment of ART & $-0.69(-1.61 ; 0.23)$ \\
\hline 38 & Undetectable viral load $(<50$ copies $/ \mathrm{ml}$ ) at week 48 & $-0.62(-2.76 ; 1.52)$ \\
\hline 39 & Treatment with Abacavir (ABC) without previous HLA-B 5701 & - \\
\hline 40 & Treatment changes during the first year & $-0.08(-0.87 ; 0.71)$ \\
\hline 41 & Record of adherence to treatment & $0.33(-0.14 ; 0.79)$ \\
\hline 42 & Study of resistance in case of virologic failure & $-0.48(-1.85 ; 0.90)$ \\
\hline 45 & ART in pregnant women with HIV & - \\
\hline 47 & Vertical transmission incidence & - \\
\hline 49 & Evaluation by CHILD or MELD for chronic liver disease & $1.67(-1.34 ; 4.67)$ \\
\hline 50 & Evaluation of the hepatitis $C$ virus coinfection & - \\
\hline 54 & HBsAg patients receiving effective treatment & - \\
\hline 55 & Ultrasound control in cirrhotic patients & $1.25(-3.23 ; 5.73)$ \\
\hline 56 & Cardiovascular risk assessment & $-0.01(-0.34 ; 0.31)$ \\
\hline
\end{tabular}

* $p$-value $<0.05$

that published in other works based on self-reported questionnaires [14, 19-21].

A low response rate may result in a response bias if the responding patients have significant differences from non-responders [22, 23]. Some authors have proposed that a response rate of at least $80 \%$ is acceptable [23, 24], while a response rate of $60 \%$ would not be adequate in terms of the representativeness of the sample [23].

Among the patients who participated in the survey, Spaniards accounted for a higher proportion, which is reasonable because the questionnaires were delivered in Spanish and English, and not all foreign patients speak those languages. The authors believe that by providing a separate space in which to complete the surveys and another in which to deliver them, both of which were outside of the consultation room, the participation of the patients was not biased.

\section{Quality indicators}

Although the level of compliance with the quality indicators was high, there are areas for improvement. With regard to some indicators, for which the subjective feeling of compliance is high, the result for the indicator was lower than the recommended standard, probably 
Table 4 Univariate analysis of other factors related to satisfaction (SUCE)

\begin{tabular}{|c|c|}
\hline \multirow[t]{2}{*}{ Other factors } & SUCE \\
\hline & Mean difference $(\mathrm{Cl} 95 \%)$ \\
\hline Age & $-0.01(-0.02 ; 0.01)$ \\
\hline \multicolumn{2}{|l|}{ Level of education } \\
\hline None & 0 \\
\hline Primary & $0.26(-0.24 ; 0.75)$ \\
\hline Secondary & $0.02(-0.47 ; 0.50)$ \\
\hline University & $0.37(-0.18 ; 0.93)$ \\
\hline \multicolumn{2}{|l|}{ Sex } \\
\hline Male & 0 \\
\hline Female & $0.18(-0.12 ; 0.49)$ \\
\hline \multicolumn{2}{|l|}{ HIV transmission category } \\
\hline PDA & 0 \\
\hline MSM & $-0.31(-1.02 ; 0.39)$ \\
\hline Heterosexual & $-0.29(-0.97 ; 0.40)$ \\
\hline \multicolumn{2}{|l|}{ Country of origin } \\
\hline Spain & 0 \\
\hline Other & $0.42(0.12 ; 0.71)^{*}$ \\
\hline Years since HIV diagnosis & $-0.01(-0.02 ; 0.01)$ \\
\hline \multicolumn{2}{|c|}{ CD4+ count $\left(\right.$ cells $\left./ \mathrm{mm}^{3}\right)$ at the time of submitting the survey } \\
\hline$<200$ & 0 \\
\hline $200-500$ & $0.23(-0.36 ; 0.82)$ \\
\hline$>500$ & $0.35(-0.19 ; 0.90)$ \\
\hline \multicolumn{2}{|c|}{ Viral load (copies $/ \mathrm{ml}$ ) at the time of delivery of the survey } \\
\hline$<50$ & 0 \\
\hline $50-100,000$ & $0.07(-0.36 ; 0.51)$ \\
\hline$>100,000$ & $0.97(-0.90 ; 2.84)$ \\
\hline
\end{tabular}

${ }^{*} p$-value $<0.05$

because there is not always a written record in the clinical history of the actions performed, for example, indicators 8-Proof of previous HIV serology, 13-Health education in the initial assessment, 25-Treatment and prevention of smoking and 41-Registration of adherence to treatment.

There is another group of indicators related to the comorbidities of patients with which the level of compliance was suboptimal: 29-Syphilis screening, 49-

Table 5 Multivariable analysis of satisfaction-related factors (SUCE)

\begin{tabular}{lc}
\hline & $\begin{array}{l}\text { Mean difference (CI 95\%) } \\
\text { SUCE }\end{array}$ \\
\hline $\begin{array}{lc}\text { Indicator } 16 & 0.55(0.08 ; 1.02) \\
\text { Country of origin (ref. Spain) } \\
\text { Other }\end{array}$ \\
\hline
\end{tabular}

Evaluation by CHILD or MELD for chronic liver disease, 55-Ultrasound control in cirrhotic patients and 56-Assessment of cardiovascular risk. Due to these results, the performance protocols have been modified, and reminders have been placed in the clinical history to improve compliance.

In the case of indicator 20-Detection of latent tuberculous infection (LTI), which evaluates the performance of LTI screening in the initial assessment, the disagreement between the number of Mantoux tuberculin skin tests requested and performed stands out; the increasingly widespread use of interferon- $\gamma$-based techniques in our setting is significantly improving compliance, as it is a technique that is routinely performed with other analyses, which avoids the need for the patient to make two trips to the hospital.

The result of indicator 26-Evaluation of alcoholic intake deserves special mention; the low level of compliance with this indicator is because in daily practice, questions about alcohol intake are asked of patients with a history of excessive consumption and not of all patients during regular follow-up as required in the definition of the indicator.

\section{User satisfaction}

The SUCE score was 9.04 points, which is higher than that obtained with the same questionnaire in other Spanish hospitals $[7,25]$. It is likely that the higher level of satisfaction is related to the fact that in the hospital conducting this study, each patient is always treated by the same physician. In satisfaction studies conducted in outpatient clinics of different specialties, patients have suggested that to improve satisfaction, they should be attended by the same doctor in successive visits $[19,20]$.

Based on the proposed cut-off value of 6.3 [15], $98.16 \%$ of patients were satisfied at the time of the interview. The low proportion of dissatisfied patients makes comparisons between satisfied and dissatisfied patients difficult. The Clinical Quality Score was higher than the Administrative Quality Score, which is a finding previously described by other authors who have worked with this questionnaire $[7,26]$.

\section{Quality indicators and user satisfaction}

An association was found between the performance of check-ups and analyses at least every 6 months and patient satisfaction; this finding should be interpreted with caution because it is possible that patients who are more satisfied with health care more regularly keep their scheduled appointments and that compliance with this indicator is the result of greater satisfaction and not cause of it.

It was also found that patients who had been vaccinated against hepatitis A virus (HAV) and 
pneumococcus were more satisfied, but those who had received a recommendation for vaccination against hepatitis B virus (HBV) were not. This disagreement suggests that although statistically significant differences were detected, their clinical relevance is probably minimal.

Compliance with the alcohol intake assessment indicator was associated with less satisfaction because, as it was applied in this population, it identifies patients with extreme alcohol consumption habits. Excessive alcohol consumption is associated with worse patient-reported satisfaction [27, 28].

In this cohort, compliance with indicator 11-Determination of plasma VL at the first visit was 100, and $88.14 \%$ of the patients had undetectable VLs when they responded to the survey, although having an undetectable HIV VL did not influence the level of satisfaction.

Some authors have analysed the complex relationship between quality management strategies and the satisfaction perceived by the patient and did not find any significant associations [6]. This fact can be explained by the low impact that the strategies implemented to increase the quality of care have on patient perceptions [6]. The direct personal relationship of the patient with the physician or the nursing staff is a powerful predictor of the patient's perception [29, 30]. To comprehensively assist patients with HIV infection, care indicators should focus not only on scientific evidence and clinical practice guidelines but should also promote the best clinical practice in other areas, such as organizational aspects, doctor-patient relationships, patient safety and medical errors [9].

\section{Strengths and limitations}

The quality indicators used in this study have been validated in the Spanish population, and have been shown to be reliable, with interobserver concordance levels greater than $95 \%$ [13].

Some studies evaluated compliance with quality standards and related their results to social, demographic, cultural and clinical factors, but no studies have contrasted these results with the level of satisfaction of the PLVIH as a user of the healthcare system. This perspective provides a more comprehensive evaluation of the quality of healthcare offered to patients.

The satisfaction questionnaire used was validated in the Spanish population and was found to have good psychometric properties. Its use enhances the reliability and validity of our results, unlike other results obtained with non-validated questionnaires $[19,20]$. The high response rate also adds value, reducing the possibility of biases and increasing the representativeness of the sample. As it is a generic questionnaire for application in outpatient clinics, it was not possible to analyse aspects specific to
HIV infection, such as the type of antiretroviral therapy (ART) used, ART dosage, etc.

Offering the questionnaires in English and Spanish may have led to participation bias because some patients were not able to read in either of those languages. Delivering them immediately after the physician's evaluation allowed the patient to recall their most recent impression and improved the quality of the information collected. The timing of the survey avoided the recall bias that would be expected if the administration of the survey had been delayed and also prevented the patient's perception from being influenced by experiences in other areas of the hospital. However, the possibility of a Hawthorne bias, which is the bias that occurs if healthcare staff members modify their habitual attitudes because they are aware that they will be evaluated, must not be overlooked; this limitation is inherent in this type of work. The small number of dissatisfied patients in our study limited the possibility of comparing satisfied and dissatisfied patients.

\section{Conclusions}

This study demonstrates the need to analyse our clinical practice with regard to the care of HIV-positive patients to identify areas of improvement and increase the level of patient satisfaction with the care received.

HIV VL is used to measure the effectiveness of ART and is important for the patient's health but is not related to their perceptions of their satisfaction with the health care they have received. The achievement of the health objectives proposed by scientific societies does not imply the fulfilment of patient expectations. Highquality health care requires that health care professionals satisfy both official requirements and patient needs.

\section{Abbreviations \\ ART: Antiretroviral therapy; Cl: Confidence interval; GeSIDA: Spanish AIDS Study Group; HAV: Hepatitis A virus; HBV: Hepatitis B virus; HCV: Hepatitis C virus; HIV: Human immunodeficiency virus; LTI: Latent tuberculous infection; MSM: Men who have sex with men; PDA: Parenteral drug addict; \\ PLHIV: People living with HIV; SUCE: External Consultation User Satisfaction Questionnaire; VL: Viral load}

\section{Acknowledgements}

Not applicable.

\section{Authors' contributions}

A. G.: Design of the work. Acquisition, analysis and interpretation of data. Drafting and revision of the work. Approval of the submitted version and agreement both to be personally accountable for the author's own contributions and to ensure that questions related to the accuracy or integrity of any part of the work are appropriately investigated, resolved, and the resolution documented in the literature. A. F.: Design of the work. Drafting and revision of the work. Approval of the submitted version and agreement both to be personally accountable for the author's own contributions and to ensure that questions related to the accuracy or integrity of any part of the work are appropriately investigated, resolved, and the resolution documented in the literature. C. M.: Design of the work. Acquisition of data. Drafting and revision of the work. Approval of the submitted version and agreement both to be personally accountable for the 
author's own contributions and to ensure that questions related to the accuracy or integrity of any part of the work are appropriately investigated, resolved, and the resolution documented in the literature. S. A.: Design of the work. Acquisition of data. Approval of the submitted version and agreement both to be personally accountable for the author's own contributions and to ensure that questions related to the accuracy or integrity of any part of the work are appropriately investigated, resolved, and the resolution documented in the literature. E.G.C.: Design of the work. Revision of the work. Approval of the submitted version and agreement both to be personally accountable for the author's own contributions and to ensure that questions related to the accuracy or integrity of any part of the work are appropriately investigated, resolved, and the resolution documented in the literature. B. A.: Analysis and interpretation of data. Drafting of the work. Approval of the submitted version and agreement both to be personally accountable for the author's own contributions and to ensure that questions related to the accuracy or integrity of any part of the work are appropriately investigated, resolved, and the resolution documented in the literature. D.C.: Acquisition of data. Drafting and revision of the work. Approval of the submitted version and agreement both to be personally accountable for the author's own contributions and to ensure that questions related to the accuracy or integrity of any part of the work are appropriately investigated, resolved, and the resolution documented in the literature. E.G.G.: Design of the work. Acquisition of data. Drafting and revision of the work. Approval of the submitted version and agreement both to be personally accountable for the author's own contributions and to ensure that questions related to the accuracy or integrity of any part of the work are appropriately investigated, resolved, and the resolution documented in the literature. P.G.: Design of the work. Acquisition of data. Drafting and revision of the work. Approval of the submitted version and agreement both to be personally accountable for the author's own contributions and to ensure that questions related to the accuracy or integrity of any part of the work are appropriately investigated, resolved, and the resolution documented in the literature. M.G.: Design of the work. Revision of the work. Approval of the submitted version and agreement both to be personally accountable for the author's own contributions and to ensure that questions related to the accuracy or integrity of any part of the work are appropriately investigated, resolved, and the resolution documented in the literature. D. V.: Design of the work. Drafting and revision of the work. Approval of the submitted version and agreement both to be personally accountable for the author's own contributions and to ensure that questions related to the accuracy or integrity of any part of the work are appropriately investigated, resolved, and the resolution documented in the literature.

\section{Funding}

This work was not funded.

\section{Availability of data and materials}

The datasets used and analysed during the current study are available from the corresponding author on reasonable request.

\section{Ethics approval and consent to participate}

The protocol of the study was approved by the Committee of Institutional Ethics (Getafe Hospital) and was in accordance with the Declaration of Helsinki for Human Research of 1974 (last modified in 2000).

\section{Consent for publication}

All patients included in the satisfaction analysis signed the patient information sheet and provided informed consent for participation in the study and subsequent publication of the data.

\section{Competing interests}

The authors declare that they have no competing interests.

\section{Author details}

${ }^{1}$ Servicio de Medicina Interna, Hospital Universitario de Torrejón. Calle Mateo Inurria S/N. 28850, Torrejón de Ardoz, Madrid, Spain. ${ }^{2}$ Universidad Francisco de Vitoria, Carretera Pozuelo-Majadahonda km 1.800, 28223 Pozuelo de Alarcón, Madrid, Spain. ${ }^{3}$ Servicio de Medicina Preventiva, Hospital Universitario de Torrejón, Calle Mateo Inurria S/N, 28850 Torrejón de Ardoz, Madrid, Spain. ${ }^{4}$ Centro Nacional de Epidemiología, Instituto de Salud Carlos
III, Avenida Monforte de Lemos 5, 28029 Madrid, Spain. ${ }^{5}$ Servicio de Medicina Interna, Hospital Perpetuo Socorro, Avda. Damián Téllez Lafuente, S/N, 06010 Badajoz, Spain. ${ }^{6}$ Servicio de Cirugía General, Hospital Universitario de Torrejón, Calle Mateo Inurria S/N, 28850 Torrejón de Ardoz, Madrid, Spain.

\section{Received: 22 November 2019 Accepted: 5 June 2020}

Published online: 15 June 2020

\section{References}

1. Soler-Palacín P, Provens AC, Martín-Nalda A, Espiau M, Fernández-Polo A, Figueras C. Indicadores de calidad asistencial para la atención de personas que viven con el virus de la inmunodeficiencia humana, adaptados a la edad pediátrica. Enferm Infecc Microbiol Clín. 2014;32:160-9.

2. Donabedian A. Evaluating the quality of medical care. Milbank Meml Fund Q. 1966:44:166-203.

3. Rodrigo-Rincón MI, Viñes-Rueda JJ, Guillén-Grima F. Utilidad del análisis multinivel en las encuestas de satisfacción para evaluar las unidades clínicas y las especialidades médicas. Rev Calid Asist. 2012;27:212-25.

4. Urzúa A. Calidad de vida relacionada con la salud: elementos conceptuales. Rev Med Chil. 2010;138:358-65.

5. Erdbeer G, Sabranski M, Sonntag I, Stoehr A, Horst H-A, Plettenberg A, et al. Everything fine so far? Physical and mental health in HIV-infected patients with virological success and long-term exposure to antiretroviral therapy. J Int AIDS Soc. 2014;17:19673.

6. Groene O, Arah OA, Klazinga NS, Wagner C, Bartels PD, Kristensen S, et al. Patient experience shows little relationship with hospital quality management strategies. PLoS One. 2015;10:e0131805.

7. Marmol MR, Cruz RM. Factores relacionados con la satisfacción en consultas externas en Hospitales de Madrid. Rev Enferm Actual Costa Rica. 2016;32: 40-51.

8. Wasson JH, Stukel T, Weiss JE, Hays RD, Jette AM, Nelson EC. A randomized trial of the use of patient self-assessment data to improve community practices. Eff Clin Pract. 1999;2:44-6.

9. Johnston S, Kendall C, Hogel M, McLaren M, Liddy C. Measures of quality of care for people with HIV: a scoping review of performance indicators for primary care. PLoS One. 2015;10:e0136757.

10. Catumbela E, Certal V, Freitas A, Costa C, Sarmento A, da Costa Pereira A. Definition of a core set of quality indicators for the assessment of HIV/AIDS clinical care: a systematic review. BMC Health Serv Res. 2013;13:236.

11. Delgado-Mejía E, Frontera-Juan G, Murillas-Angoiti J, Campins-Roselló AA, Gil-Alonso L, Peñaranda-Vera $M$, et al. Indicadores de calidad asistencial de GeSIDA para la atención de personas infectadas por el $\mathrm{VIH} /$ sida asociados a mortalidad e ingreso hospitalario. Enferm Infecc Microbiol Clín. 2017;35:67-75.

12. von Wichmann MÁ, Locutura J, Blanco JR, Riera M, Suárez-Lozano I, Saura RM, et al. Indicadores de calidad asistencial de GESIDA para la atención de personas infectadas por el VIH/sida. Enferm Infecc Microbiol Clín. 2010;28:6-88.

13. Riera M, Esteban H, Suarez I, Palacios R, Lozano F, Blanco JR, et al. Validación y cumplimentación de los indicadores de calidad GESIDA en pacientes con infección por el VIH. Enferm Infecc Microbiol Clín. 2016;34:346-52.

14. Granado de la Orden S, Rodríguez Rieiro C, MdC OL, Chacón García A, Vigil Escribano D, Rodríguez Pérez P. Diseño y validación de un cuestionario para evaluar la satisfacción de los pacientes atendidos en las consultas externas de un hospital de Madrid en 2006. Rev Esp Salud Pública. 2007;81:637-45.

15. Granado de la Orden S. Metodología para evaluar la satisfacción de los pacientes de un hospital público (Tesis Doctoral). Madrid: Universidad Autónoma de Madrid; 2008.

16. Rivero A, Pérez-Molina JA, Blasco AJ, Arribas JR, Crespo M, Domingo $P$, et al. Costs and cost-efficacy analysis of the 2016 GESIDA/Spanish AIDS national plan recommended guidelines for initial antiretroviral therapy in HIVinfected adults. Enferm Infecc Microbiol Clín. 2017;35:88-99.

17. Sobrino-Vegas P, Gutiérrez F, Berenguer J, Labarga P, García F, AlejosFerreras B, et al. La cohorte de la red española de investigación en sida y su biobanco: organización, principales resultados y pérdidas al seguimiento. Enferm Infecc Microbiol Clín. 2011;29:645-53.

18. de las Robustillo-Cortés MA, Goitia BT, Sánchez ER, Barrientos ET, PMÁ d S, Verdugo RM. Analysis of the implementation of GESIDA quality indicators in the HIV + cohort PSITAR. Rev Organ Farm Íbero-Latinoam. 2016;26:251-7.

19. Pérez-Blanco V, García-Caballero J, Cisneros J, Tabernero Á. Satisfacción del paciente urológico en consultas externas. Rev Calid Asist. 2003;18:628-35. 
20. Ramírez Hernández M, Mérida Fernández C, Negro Álvarez JM, Félix Toledo M, Martínez López RM. Satisfacción de los pacientes asistidos en una consulta externa de alergología. Alergol Inmunol Clín. 2004;19:145-52.

21. Miners A, Phillips A, Kreif N, Rodger A, Speakman A, Fisher M, et al. Healthrelated quality-of-life of people with HIV in the era of combination antiretroviral treatment: a cross-sectional comparison with the general population. Lancet HIV. 2014;1:e32-40.

22. Sitzia J, Wood N. Response rate in patient satisfaction research: an analysis of 210 published studies. Int I Qual Health Care. 1998;10:311-7.

23. Dawson J, Doll H, Fitzpatrick R, Jenkinson C, Carr AJ. The routine use of patient reported outcome measures in healthcare settings. BMJ. 2010;340: c186.

24. Rose G, Barker DJ. Epidemiology for the uninitiated: conduct of surveys. $\mathrm{Br}$ Med J. 1978;2:1201-2.

25. Hernández-García I, González-Torga A, Villanueva-Ruiz C, García-Shimizu P, Martín-Ruiz AC, Arnau-Santos M. Satisfacción de los pacientes atendidos en una consulta externa de medicina preventiva. Rev Calid Asist. 2010;25:83-9.

26. Redhead GR. Calidad de servicio y satisfacción del usuario en el centro de salud miguel grau distrito de chaclacayo 2013 [Tesis]. Lima: Universidad Nacional Mayor de San Marcos; 2015.

27. Kim KH, Kim JS. The association between alcohol consumption patterns and health-related quality of life in a nationally representative sample of south Korean adults. PLoS One. 2015;10:e0119245.

28. Levola J, Aalto M, Holopainen A, Cieza A, Pitkänen T. Health-related quality of life in alcohol dependence: a systematic literature review with a specific focus on the role of depression and other psychopathology. Nord Psychiatry. 2013;68:369-84

29. De Vries AMM, de Roten Y, Meystre C, Passchier J, Despland JN, Stiefel F. Clinician characteristics, communication, and patient outcome in oncology: a systematic review. Psychooncology. 2013;23:375-81.

30. Edwards A, Elwyn G, Hood K, Robling M, Atwell C, Holmes-Rovner M, et al. The development of COMRADE-a patient-based outcome measure to evaluate the effectiveness of risk communication and treatment decision making in consultations. Patient Educ Couns. 2003;50:311-22.

\section{Publisher's Note}

Springer Nature remains neutral with regard to jurisdictional claims in published maps and institutional affiliations.

Ready to submit your research? Choose BMC and benefit from:

- fast, convenient online submission

- thorough peer review by experienced researchers in your field

- rapid publication on acceptance

- support for research data, including large and complex data types

- gold Open Access which fosters wider collaboration and increased citations

- maximum visibility for your research: over $100 \mathrm{M}$ website views per year

At $\mathrm{BMC}$, research is always in progress.

Learn more biomedcentral.com/submissions 